EISSN: 2706 -7947 ISSN: 2077- 4613

DOI: 10.36632/mejas/2021.11.4.74

Journal homepage: www.curresweb.com

Pages: 948-958

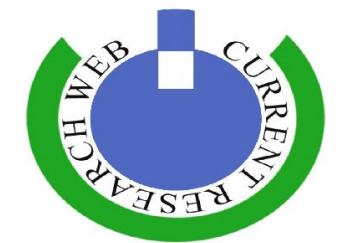

\title{
Enhancement of Faba Bean (Vicia faba) Growth and Yield Grown in New Reclaimed Sandy Soil by Treatment with Benzyladenine or Yeast Extract
}

\author{
Faten S.A. Zaki, Karima M.G. El-Din, Mervat S.h. Sadak, Magda A.F. Shalaby, \\ Mohamed El-Sayed El-Awadi and Sohair K. Ibrahim
}

Botany Department, National Research Centre, 33 El-Buhouth St., Dokki, Giza, Egypt. Postal Code: 12622.

\author{
Received: 10 Oct. $2021 \quad$ Accepted: 15 Nov. $2021 \quad$ Published: 25 Nov. 2021
}

\begin{abstract}
Two field experiments were carried out at the Research and Production Station of National Research Centre, Nubaria region, Behira Governorate, Egypt, during two winter seasons 2019-2020 and 20202021. This work aimed to study the enhancement of foliar application of benzyladenine (BA) at 25, 50, $75 \mathrm{mg} / \mathrm{L}$ or the bio-stimulant (yeast extract at $1,2,3 \mathrm{~g} / \mathrm{L}$ ) on growth and quantity and quality of the yield of two cultivars of faba bean (Cvs Misr 3 and Nubaria 2) under sandy soil condition. Data showed that the two used growth regulators compound increased vegetative characters (i.e. shoot length, number of branches and leaves as well as photosynthetic pigments. Treatment with BA or yeast extract concentrations increased number and weight of pods and seeds as well as the biochemical constituents of seeds. The most positive effects were attained by application of highest concentrations of BA (75 $\mathrm{mg} / \mathrm{L})$ and yeast extract $(3 \mathrm{~g} / \mathrm{L})$ for variant Nubaria 2 and surpassed variant Misr 3 by the same concentrations. Application of BA at concentration $75 \mathrm{mg} / 1$ to Misr 3 exhibits the least amount of antinutritional compound vicine as well as the highest percentage of reduction.
\end{abstract}

Keywords: Faba Bean foliar application, bio-stimulant, benzyladenine (BA), growth, yield

\section{Introduction}

Faba bean (Vicia faba L.) is considered as the main leguminous crops grown in Egypt. It is a good source of protein and carbohydrate for human and animal food. The seed content of protein about $30 \%$ of dry weight of the seeds, which contains most of the necessary amino acids for human nutrition. This crop can also be grown successfully in sandy soil (Bakry et al., 2011; Megawer et al., 2017 and Dawood et al., 2019). So, it is important to maximize the yield of faba bean especially in the new reclaimed sandy soil to fulfill the gap between production and consumption.

Cytokinins are important group of plant hormones. They have been implicated in many facts of plant growth and development, including cell division and differentiation, alleviation of photosynthetic pigments building, number of metabolic processes, as well as fruit and seed development. Benzyladenine (BA) is one of the most effective member of this group (Van Staden et al., 1996; Patil et al., 2002).

Agricultural production seeks natural safety substance technological solutions to improve quantity and quality of the yield of many crops, therefore, bio-stimulants are increasingly popular as preparations that favorably impact of growth, development and yield of several plants and enhance the tolerance or crop quality (Van Oosten et al., 2017).

Later, du Jardin et al., (2012); pointed out that bio-stimulants are modulators of life processes in plants that enhance growth and resource use efficiency, under stress or non-stress conditions.

Yeast is an important bio-stimulant. It is considered as natural source for various amino acids, vitamins and nutrients (Barnett et al., 1990). Many studies showed that the effective role of yeast with regard to growth and yield of leguminous plants (Abou El-yazied and Mady, 2012; Marzauk et al., 2014on Vicia faba Khalil and Ismael 2010on Lupinus termis and Abed Nasser et al., 2019on Lens ) 
High yielding ability cultivar is considered among the important agricultural practices, that judging the vegetative growth as well as productivity of faba bean cultivars (Bakry et al., 2011; Abo El-Hamad et al., 2015 and Abdel-Baky et al., 2019).

The aim of the present study is to assess the impact of spraying BA or yeast on two cultivars of faba bean (Misr 3 and Nubaria 2) on growth, yield and some biochemical constituents of the yield seeds to define the suitable treatment and cultivar to improve the yield.

\section{Materials and Methods}

\subsection{Plant materials and experimental conditions}

Two field experiments were conducted at the Research and Production Station, National Research Centre, El-Nubaria Province, El-Behira Governorate, Egypt, during two successive winter seasons of 2018/2019 and 2019/2020. The seeds of two faba bean cultivars (Masr 3 and Nubaria 2) were obtained from the Legumes Crops Research Department, Ministry of Agriculture, Egypt and selected for uniformity in size and color.

Regarding fertilization, $\mathrm{P}_{2} \mathrm{O}_{5}$ as calcium superphosphate $(15.5 \%)$ and $\mathrm{K}_{2} \mathrm{O}$ as potassium sulphate (48\%) were added during seed bed preparation at the level of 31 and $24 \mathrm{~kg} /$ fed respectively, while nitrogen fertilizer as ammonium nitrate $(33.5 \%)$ was added at the rate of $75 \mathrm{~kg} \mathrm{~N} /$ fed. Seeds of faba bean were sown in hill spaced $20 \mathrm{~cm}$ apart at both sides of ridge on the middle of November during the two growing seasons. Thinning was carried out at 15 days after sowing to leave two plants per hill. The experiments were laid out in factorial experiment in complete randomized block design with four replicates/treatment. The experimental unit was $10.5 \mathrm{~m}^{2}$ (1/400 fed.) 3 meter long and 3.5 meter wide and $60 \mathrm{~cm}$ apart between rows. The plants were sprayed twice at 30 and 45 days after sowing with freshly prepared solutions of benzyladenine (BA) at $25,50,75 \mathrm{mg} / \mathrm{L}$ or the bio-stimulate (yeast extract at $1,2,3 \mathrm{~g} / \mathrm{L}$ ). Meanwhile, untreated plants were sprayed by distilled water to serve as control. Irrigation was carried out using the sprinkler irrigation system where plants were watered every 5 days for two hours.

\subsection{Data recorded}

Plant samples were collected after 60 days from sowing for measurement of some growth parameters (shoot length, leaves and branches number/plant, dry weight of plant) and photosynthetic pigments in fresh leaf.

At harvest the following characters were recorded at random of ten guarded plants from each treatment: number and weight of pods / plant, number of seeds /plant, seed yield / plant (g), weight of straw/plant (g). The yielded seeds were cleaned and crushed to determine total carbohydrate, total protein, vicine content, and $\mathrm{N}, \mathrm{P}, \mathrm{K}$ elements.

\subsection{Chemical analysis}

Chlorophyll a, chlorophyll $\mathrm{b}$ and carotenoids were determined using method described by Lichtenthaler and Buschmann (2001). Phosphorus (P), potassium (K) and nitrogen (N) were measured in the yielded seeds. The seeds were digested using an acid mixture consisting of nitric, perchloric and sulfuric acids in the ratio of $8: 1: 1(\mathrm{v} / \mathrm{v})$. Phosphorus and potassium were estimated photo-metrically using flame photometer method described by the methods described by Chapman and Pratt (1978). Total nitrogen $(\mathrm{N})$ was determined using micro-Kjeldahl method, as described by AOAC (2000).Total protein was calculated by multiplying $\mathrm{N} \%$ by 6.25 .The total carbohydrate was determined according method described by Dubois et al., 1956). Vicine content was determined according to Collier (1976).

\section{Results}

\subsection{Growth parameters}

Results presented in Table (1) show that Misr 3 (M3) cultivar surpassed Nubaria 2 (N2) in shoot length and number of leaves/plant, however, no significant difference in number of branches/plant and dry weight/plant. 
Concerning the effect of benzyladenine (BA) or yeast extract (Table 1), significant difference were attained with the used concentrations of BA or yeast extract with all vegetative characters (shoot length, number of branches and leaves as well as dry weight).

The interaction processes exhibits obvious high significant increase of shoot length due to application of the two concentrations $(50,75 \mathrm{mg} / \mathrm{L}) \mathrm{BA}$ with regard to cultivar M3. As to cultivar N2 the highest concentration of BA $(75 \mathrm{mg} / \mathrm{L})$ surpassed the other treatment of BA or yeast.

Treatment with the two higher concentrations of BA $(50,75 \mathrm{mg} / \mathrm{L})$ or yeast extract $(2,3 \mathrm{~g} / \mathrm{L})$ exerts high significant increase of number of branches/plant for the two cultivars (M3 and N2).

Number of leaves/plant shows significant increase due to application of two higher concentrations of BA with respect to cultivar (M3), meanwhile, 2 and $3 \mathrm{~g} / \mathrm{L}$ concentrations of yeast treatments resulted in the highest significant number of leaves/plant for cultivar (N2).

Dry weight of shoots indicated that spraying plants with BA 50 and $75 \mathrm{mg} / \mathrm{L}$ BA to cultivar (N2) exhibited the highest significant increase of dry weight/plant (Table 1).

Table 1: Effect of benzyladenine or yeast extract on some growth characters of Misr 3 and Nubaria 2 Cultivars (Combined analysis of two seasons)

\begin{tabular}{|c|c|c|c|c|c|}
\hline & & $\begin{array}{c}\text { Shoot length } \\
\text { (cm) }\end{array}$ & $\begin{array}{c}\begin{array}{c}\text { No. of leaves/ } \\
\text { plant }\end{array} \\
\end{array}$ & $\begin{array}{c}\text { No. of branches/ } \\
\text { plant }\end{array}$ & $\begin{array}{c}\text { Dry weight/plant } \\
\text { (g) }\end{array}$ \\
\hline \multicolumn{6}{|c|}{ Effect of cultivars } \\
\hline Misr 3 & & $53.76 \mathrm{a}$ & $18.43 \mathrm{~b}$ & $1.81 \mathrm{a}$ & $7.03 \mathrm{a}$ \\
\hline Nubaria2 & & $49.33 b$ & $12.95 \mathrm{a}$ & $2.00 \mathrm{a}$ & $8.57 \mathrm{a}$ \\
\hline LSD at $5 \%$ & & 1.88 & 1.02 & 0.21 & 1.68 \\
\hline \multicolumn{6}{|c|}{ Effect of BA and Yeast } \\
\hline Control & & $44.67 \mathrm{e}$ & $17.00 \mathrm{~d}$ & $1.00 \mathrm{c}$ & $6.60 \mathrm{c}$ \\
\hline BA $(25 \mathrm{mg} / \mathrm{L}$ & & $51.17 \mathrm{~cd}$ & $18.17 \mathrm{c}$ & $2.00 \mathrm{ab}$ & $7.25 \mathrm{bc}$ \\
\hline BA $(50 \mathrm{mg} / \mathrm{L}$ & & $55.67 \mathrm{~b}$ & $20.33 b$ & $2.00 \mathrm{ab}$ & $7.90 \mathrm{ab}$ \\
\hline BA $(75 \mathrm{mg} / \mathrm{L}$ & & $59.83 \mathrm{a}$ & $22.00 \mathrm{a}$ & $2.17 \mathrm{ab}$ & $8.35 \mathrm{ab}$ \\
\hline Yeast $(1 \mathrm{~g} / \mathrm{L})$ & & $48.33 \mathrm{~d}$ & $20.17 b$ & $1.67 \mathrm{~b}$ & $7.79 \mathrm{ab}$ \\
\hline Yeast $(2 \mathrm{~g} / \mathrm{L})$ & & $49.50 \mathrm{c}$ & $20.83 b$ & $2.17 \mathrm{ab}$ & $8.18 \mathrm{ab}$ \\
\hline Yeast $(3 \mathrm{~g} / \mathrm{L})$ & & $51.67 \mathrm{c}$ & $22.83 \mathrm{a}$ & $2.33 \mathrm{a}$ & $8.54 \mathrm{a}$ \\
\hline LSD at $5 \%$ & & 2.99 & 1.01 & 0.54 & 1.02 \\
\hline \multicolumn{6}{|c|}{ Effect of Interaction } \\
\hline \multirow{7}{*}{ Misr 3} & Control & $48.33 \mathrm{~cd}$ & $16.00 \mathrm{~h}$ & $1.00 \mathrm{c}$ & $5.73 \mathrm{f}$ \\
\hline & BA $(25 \mathrm{mg} / \mathrm{L})$ & $52.00 \mathrm{bc}$ & $16.33 \mathrm{gh}$ & $2.00 \mathrm{ab}$ & $6.09 \mathrm{ef}$ \\
\hline & BA $(50 \mathrm{mg} / \mathrm{L})$ & $58.33 \mathrm{a}$ & $20.33 \mathrm{de}$ & $2.00 \mathrm{ab}$ & $6.19 \mathrm{ef}$ \\
\hline & BA $(75 \mathrm{mg} / \mathrm{L})$ & $60.33 \mathrm{a}$ & $21.33 \mathrm{~cd}$ & $2.00 \mathrm{ab}$ & $6.71 \mathrm{def}$ \\
\hline & Yeast $(1 \mathrm{~g} / \mathrm{L})$ & $51.00 \mathrm{bc}$ & $17.67 \mathrm{fg}$ & $1.33 b c$ & $7.56 \mathrm{cde}$ \\
\hline & Yeast $(2 \mathrm{~g} / \mathrm{L})$ & $53.00 \mathrm{bc}$ & $18.33 \mathrm{f}$ & $2.00 \mathrm{ab}$ & $8.27 \mathrm{bcd}$ \\
\hline & Yeast $(3 \mathrm{~g} / \mathrm{L})$ & $53.33 \mathrm{~b}$ & $19.00 \mathrm{ef}$ & $2.33 \mathrm{a}$ & $8.68 \mathrm{abc}$ \\
\hline \multirow{7}{*}{ Nubaria 2} & Control & $41.00 \mathrm{e}$ & $18.00 \mathrm{f}$ & $1.00 \mathrm{c}$ & $7.48 \mathrm{cde}$ \\
\hline & BA $(25 \mathrm{mg} / \mathrm{L})$ & $53.33 \mathrm{bcd}$ & $20.00 \mathrm{de}$ & $2.00 \mathrm{ab}$ & $8.41 b c$ \\
\hline & BA $(50 \mathrm{mg} / \mathrm{L})$ & $53.00 \mathrm{bc}$ & $20.33 \mathrm{de}$ & $2.00 \mathrm{ab}$ & $9.61 \mathrm{ab}$ \\
\hline & BA (75mg/L) & $59.33 \mathrm{a}$ & $22.67 \mathrm{bc}$ & $2.33 \mathrm{a}$ & $9.99 a$ \\
\hline & Yeast (1g/L) & $45.67 d$ & $22.67 \mathrm{bc}$ & $2.00 \mathrm{ab}$ & $8.02 \mathrm{bcd}$ \\
\hline & Yeast $(2 \mathrm{~g} / \mathrm{L})$ & $46.00 \mathrm{~d}$ & $23.33 b$ & $2.33 \mathrm{a}$ & $8.09 \mathrm{bcd}$ \\
\hline & Yeast $(3 g / L)$ & $50.00 \mathrm{bcd}$ & $26.67 \mathrm{a}$ & $2.33 \mathrm{a}$ & $8.39 b c$ \\
\hline LSD at $5 \%$ & & 4.23 & 1.42 & 0.76 & 1.44 \\
\hline
\end{tabular}

\subsection{Photosynthetic Pigments.}

Data of photosynthetic pigments (chlorophyll $\mathrm{a}$, chlorophyll $\mathrm{b}$ and carotenoids) shown no significant difference between the two cultivar M3 and N2 (Table 2).

Treating faba bean with BA or yeast (Table 2) results in high significant increase due to spraying faba bean plants with the highest concentrations of BA $(75 \mathrm{mg} / \mathrm{L})$ or yeast extracts $(3 \mathrm{~g} / \mathrm{L})$ with regard to the studied photosynthetic pigments

The interaction of faba bean cultivars and used concentrations of BA and yeast (Table 2), similar significant increases were obtained in the studied photosynthetic pigments compared to control plants. 
The treatments with BA at $75 \mathrm{mg} / \mathrm{L}$ or yeast at $3 \mathrm{~g} / \mathrm{L}$ show the superior significant increase of chlorophyll $(a, b)$ and carotenoids with regard to the two cultivars (M3and N2).

Table 2: Effect of benzyladenine or yeast extract on photosynthetic pigment of Misr 3 and Nubaria 2 Cultivars (Combined analysis of two seasons)

\begin{tabular}{|c|c|c|c|c|c|}
\hline & & $\begin{array}{c}\text { Chlorophyll a } \\
\text { (mg/gfwt.) }\end{array}$ & $\begin{array}{c}\text { Chlorophyll b } \\
\text { (mg/gfwt.) }\end{array}$ & $\begin{array}{c}\text { Carotenoids } \\
\text { (mg/gfwt.) }\end{array}$ & $\begin{array}{c}\text { Total } \\
\text { photosynthetic } \\
\text { pigments (mg/g } \\
\text { fwt.) } \\
\end{array}$ \\
\hline \multicolumn{6}{|c|}{ Effect of cultivars } \\
\hline Misr 3 & & $1.19 \mathrm{a}$ & $0.33 \mathrm{a}$ & $024 a$ & $1.67 \mathrm{a}$ \\
\hline Nubaria2 & & $1.27 \mathrm{a}$ & $0.34 \mathrm{a}$ & $0.24 \mathrm{a}$ & $1.72 \mathrm{a}$ \\
\hline LSD at $5 \%$ & & 1.10 & 0.04 & 0.04 & 0.07 \\
\hline \multicolumn{6}{|c|}{ Effect of BA and Yeast } \\
\hline Control & & $1.09 \mathrm{c}$ & $0.25 \mathrm{c}$ & $0.21 \mathrm{c}$ & $1.56 \mathrm{~d}$ \\
\hline BA $(25 \mathrm{mg} / \mathrm{L}$ & & $119 b c$ & $0.33 \mathrm{~b}$ & $0.23 \mathrm{abc}$ & $163 \mathrm{~cd}$ \\
\hline BA $(50 \mathrm{mg} / \mathrm{L}$ & & $1.20 \mathrm{bc}$ & $0.35 \mathrm{ab}$ & $0.25 \mathrm{abc}$ & $1.66 \mathrm{~cd}$ \\
\hline BA $(75 \mathrm{mg} / \mathrm{L}$ & & $1.34 \mathrm{bc}$ & $0.38 \mathrm{a}$ & $0.27 \mathrm{a}$ & $1.84 \mathrm{a}$ \\
\hline Yeast $(1 \mathrm{~g} / \mathrm{L})$ & & $1.17 b c$ & $0.34 \mathrm{ab}$ & $0.22 b c$ & $1.71 b c$ \\
\hline Yeast $(2 \mathrm{~g} / \mathrm{L})$ & & $125 \mathrm{ab}$ & $0.35 \mathrm{ab}$ & $25 \mathrm{abc}$ & $1.71 b c$ \\
\hline Yeast $(3 \mathrm{~g} / \mathrm{L})$ & & $1.36 \mathrm{a}$ & $0.37 \mathrm{a}$ & $025 \mathrm{ab}$ & $1.77 \mathrm{ab}$ \\
\hline LSD at $5 \%$ & & 0.12 & 0.04 & 0.04 & 0.09 \\
\hline \multicolumn{6}{|c|}{ Effect of Interaction } \\
\hline \multirow{7}{*}{ Misr 3} & Control & $1.08 \mathrm{~d}$ & $0.28 \mathrm{c}$ & $0.22 \mathrm{abc}$ & $1.53 \mathrm{e}$ \\
\hline & BA $(25 \mathrm{mg} / \mathrm{L})$ & $1.14 \mathrm{~cd}$ & $030 \mathrm{bc}$ & $0.24 a b c$ & $1.57 \mathrm{de}$ \\
\hline & BA $(50 \mathrm{mg} / \mathrm{L})$ & $1.14 \mathrm{~cd}$ & $0.33 \mathrm{abc}$ & $0.24 a b c$ & $1.59 \mathrm{cde}$ \\
\hline & BA $(75 \mathrm{mg} / \mathrm{L})$ & $1.32 \mathrm{abc}$ & $0.37 \mathrm{a}$ & $0.28 \mathrm{a}$ & $1.82 \mathrm{ab}$ \\
\hline & Yeast $(1 \mathrm{~g} / \mathrm{L})$ & $1.10 \mathrm{~d}$ & $0.34 \mathrm{ab}$ & $0.21 \mathrm{bc}$ & $1.70 \mathrm{bcd}$ \\
\hline & Yeast $(2 \mathrm{~g} / \mathrm{L})$ & $1.26 \mathrm{abcd}$ & $0.35 \mathrm{ab}$ & $0.24 \mathrm{abc}$ & $1.72 \mathrm{abcd}$ \\
\hline & Yeast $(3 \mathrm{~g} / \mathrm{L})$ & $1.28 \mathrm{abcd}$ & $0.38 \mathrm{a}$ & $0.25 \mathrm{abc}$ & $1.78 \mathrm{ab}$ \\
\hline \multirow{7}{*}{ Nubaria 2} & Control & $1.11 \mathrm{~d}$ & $0.23 \mathrm{~d}$ & $0.20 \mathrm{c}$ & $1.59 \mathrm{cde}$ \\
\hline & BA $(25 \mathrm{mg} / \mathrm{L})$ & $1.23 \mathrm{bcd}$ & $0.35 \mathrm{ab}$ & $0.23 \mathrm{abc}$ & $1.69 \mathrm{bcd}$ \\
\hline & BA $(50 \mathrm{mg} / \mathrm{L})$ & $1.26 \mathrm{abcd}$ & $0.37 \mathrm{a}$ & $0.25 \mathrm{abc}$ & $1.73 \mathrm{abc}$ \\
\hline & BA $(75 \mathrm{mg} / \mathrm{L})$ & $1.36 \mathrm{ab}$ & $0.38 \mathrm{a}$ & $0.25 \mathrm{abc}$ & $1.86 \mathrm{a}$ \\
\hline & Yeast $(1 \mathrm{~g} / \mathrm{L})$ & $1.23 \mathrm{bcd}$ & $0.35 \mathrm{ab}$ & $0.23 \mathrm{abc}$ & 17.1 abcd \\
\hline & Yeast $(2 \mathrm{~g} / \mathrm{L})$ & $1.25 \mathrm{abcd}$ & $0.35 \mathrm{ab}$ & $0.25 \mathrm{abc}$ & $1.71 \mathrm{bcd}$ \\
\hline & Yeast $(3 \mathrm{~g} / \mathrm{L})$ & $1.43 \mathrm{a}$ & $0.36 \mathrm{ab}$ & $0.26 \mathrm{ab}$ & $1.76 \mathrm{ab}$ \\
\hline LSD at $5 \%$ & & 0.17 & 0.05 & 0.05 & 0.13 \\
\hline
\end{tabular}

\subsection{Seed yield an its components}

Data presented in Table (3) show that the two used cultivars exhibits significant differences and cultivar M3 surpassed cultivar N2 in the studied attributes of yield (number and weight of pods and seeds/plant). However, the results show no significant difference of straw weight (Table 3 )

Treatment with BA or yeast increased significantly all studied criteria of pods and seeds as well as weight of straw/plant. Maximum significant increases were attained by the highest concentrations of BA or yeast extract with regard to number and weight of pods and seeds/plant. As to straw weight BA concentration at $75 \mathrm{mg} / \mathrm{L}$ resulted in the highest significant increase comparing to other treatments (Table 3).

As to the interaction Table (3) shows the superiority of application BA at the highest concentration $(75 \mathrm{mg} / \mathrm{L})$ with regard to cultivar (N2) in increasing number and weight of pods followed by cultivar M3.

Concerning number and weight of seeds/planttreatment with $75 \mathrm{mg} / \mathrm{L}$ still exits the highest effect in increasing number and weight of seeds/plant of cultivar N2 followed by treatment with yeast extract $(3 \mathrm{~g} / \mathrm{L})$ for the same cultivar.

Data of weight of straw/plant clarify that treatment with BA $(75 \mathrm{mg} / \mathrm{L})$ resulted in the highest increase of straw with regard to cultivar N2 followed by the same concentration to cultivar M3. 
Table 3: Effect of benzyladenine or yeast extract on seed yield and yield components of Misr 3 and Nubaria 2 Cultivars (Combined analysis of two seasons)

\begin{tabular}{|c|c|c|c|c|c|c|}
\hline & & $\begin{array}{l}\text { Number of } \\
\text { Pods/plant }\end{array}$ & $\begin{array}{l}\text { Number of } \\
\text { seeds/plant }\end{array}$ & $\begin{array}{c}\text { Weight of } \\
\text { pods/plant } \\
\text { (g) }\end{array}$ & $\begin{array}{l}\text { Weight of } \\
\text { seeds/plant } \\
\text { (g) }\end{array}$ & $\begin{array}{l}\text { Weight of } \\
\text { straw/M}\end{array}$ \\
\hline & & & ff cultivars & & & \\
\hline Misr 3 & & $7.58 \mathrm{a}$ & $19.13 \mathrm{a}$ & $18.48 \mathrm{a}$ & $15.48 \mathrm{a}$ & $1315 a$ \\
\hline Nubaria2 & & $7.16 \mathrm{~b}$ & $14.99 b$ & $17.22 b$ & $12.04 \mathrm{~b}$ & $13.27 \mathrm{a}$ \\
\hline LSD at 5 & & 0.21 & 0.41 & 0.10 & 0.35 & 0.35 \\
\hline & & Eff & f Treatment & & & \\
\hline Control & & $5.22 \mathrm{~d}$ & $11.78 \mathrm{f}$ & $12.16 \mathrm{f}$ & $9.22 \mathrm{~g}$ & $8.98 \mathrm{~g}$ \\
\hline BA $(25 \mathrm{~m} \xi$ & & $7.16 b c$ & $14.99 \mathrm{e}$ & $17.22 \mathrm{~d}$ & $12.04 \mathrm{f}$ & $13.27 \mathrm{c}$ \\
\hline BA $(50 \mathrm{mg}$ & $/ \mathrm{L})$ & $7.30 \mathrm{bc}$ & $15 . .80 \mathrm{~d}$ & $17.70 \mathrm{c}$ & $12.66 \mathrm{e}$ & $14.72 b$ \\
\hline BA $(75 \mathrm{~m}$ & $/ \mathrm{L})$ & $8.22 \mathrm{a}$ & $22.56 \mathrm{a}$ & $23.23 \mathrm{a}$ & $16.66 \mathrm{a}$ & $18.73 a$ \\
\hline Yeast (1g & & $6.81 \mathrm{c}$ & $14.74 \mathrm{e}$ & $16.24 \mathrm{c}$ & $13.69 \mathrm{~d}$ & $10.24 \mathrm{f}$ \\
\hline Yeast (2g & & $769 \mathrm{ab}$ & $16.41 \mathrm{c}$ & $17.77 \mathrm{c}$ & $14.30 \mathrm{c}$ & $10.03 \mathrm{e}$ \\
\hline Yeast (3g & & $8.01 \mathrm{a}$ & $17.83 b$ & $18.49 \mathrm{~b}$ & $14.88 \mathrm{~b}$ & $11.60 \mathrm{c}$ \\
\hline LSD at $5^{\circ}$ & & 0.58 & 0.48 & 0.33 & 0.57 & 0.50 \\
\hline & & Effe & Interaction & & & \\
\hline & Control & $4.59 \mathrm{~g}$ & $9.68 \mathrm{~h}$ & $10.75 \mathrm{~h}$ & $8.46 \mathrm{~g}$ & $8.16 \mathrm{~h}$ \\
\hline & BA $(25 \mathrm{mg} / \mathrm{L})$ & $6.30 \mathrm{ef}$ & $12.53 \mathrm{~g}$ & $16.13 \mathrm{f}$ & $10.11 \mathrm{f}$ & $13.59 \mathrm{~d}$ \\
\hline & BA $(50 \mathrm{mg} / \mathrm{L})$ & $6.30 \mathrm{ef}$ & $13.23 \mathrm{f}$ & $16.30 \mathrm{f}$ & $10.70 \mathrm{f}$ & $14.98 \mathrm{c}$ \\
\hline Misr & BA $(75 \mathrm{mg} / \mathrm{L})$ & $7.35 \mathrm{~cd}$ & $17.04 d$ & $19.85 b$ & $13.70 \mathrm{~d}$ & $17.37 \mathrm{~b}$ \\
\hline & Yeast $(1 \mathrm{~g} / \mathrm{L})$ & $7.13 \mathrm{de}$ & $12.39 \mathrm{~g}$ & $16.38 \mathrm{f}$ & $10.82 \mathrm{f}$ & $10.14 \mathrm{~g}$ \\
\hline & Yeast $(2 \mathrm{~g} / \mathrm{L})$ & $9.97 \mathrm{bcd}$ & $13.50 \mathrm{f}$ & $18.26 \mathrm{~d}$ & $11.99 \mathrm{e}$ & $10.30 \mathrm{~g}$ \\
\hline & Yeast $(3 \mathrm{~g} / \mathrm{L})$ & $8.12 b c$ & $15.97 \mathrm{e}$ & $18.59 \mathrm{~d}$ & $12.76 \mathrm{e}$ & $10.57 \mathrm{~g}$ \\
\hline & Control & $5.86 \mathrm{f}$ & $13.88 \mathrm{f}$ & $13.57 \mathrm{~g}$ & $9.98 \mathrm{f}$ & $9.80 \mathrm{~g}$ \\
\hline & BA $(25 \mathrm{mg} / \mathrm{L})$ & $8.02 \mathrm{bcd}$ & $17.45 \mathrm{~d}$ & $18.31 d$ & $13.97 \mathrm{~cd}$ & 12.96de \\
\hline & BA $(50 \mathrm{mg} / \mathrm{L})$ & $8.30 \mathrm{ab}$ & $18.38 \mathrm{c}$ & $19.10 \mathrm{c}$ & $14.63 \mathrm{c}$ & $14.46 \mathrm{c}$ \\
\hline Nubaria & BA $(75 \mathrm{mg} / \mathrm{L})$ & $9.08 \mathrm{a}$ & $28.08 \mathrm{a}$ & 26.61a & $19.63 \mathrm{a}$ & $20.09 a$ \\
\hline & Yeast $(1 \mathrm{~g} / \mathrm{L})$ & $6.49 \mathrm{ef}$ & $17.08 \mathrm{~d}$ & $16.11 \mathrm{f}$ & $16.56 \mathrm{~b}$ & $10.34 \mathrm{~g}$ \\
\hline & Yeast $(2 \mathrm{~g} / \mathrm{L})$ & $7.42 \mathrm{bcd}$ & $19.32 b$ & $17.29 \mathrm{e}$ & $16.61 \mathrm{~b}$ & $11.34 \mathrm{~g}$ \\
\hline & Yeast $(3 \mathrm{~g} / \mathrm{L})$ & $7.90 \mathrm{bcd}$ & $19.70 \mathrm{~b}$ & $18.39 \mathrm{~d}$ & $16.99 \mathrm{~b}$ & $12.62 \mathrm{e}$ \\
\hline LSD at 5 & & 0.82 & 0.68 & 0.46 & 0.46 & 0.81 \\
\hline
\end{tabular}

\subsection{Biochemical constituents of the yield seed}

It is clear that cultivar (M3) surpassed (N2) cultivar in nitrogen content as well as protein ratio and carbohydrate concentration. In the meantime cultivar N2 shows significant increase in PK content (Table 4).

As to the effect of BA or yeast, treatment with the highest concentration $(75 \mathrm{mg} / \mathrm{L})$ of BA resulted in the highest significant increase in all nutritional elements and compounds $(\mathrm{N}, \mathrm{P}, \mathrm{K}$, protein, total carbohydrate). In the meantime $2 \mathrm{~g} / \mathrm{L}$ of yeast extract resulted in significant increase of $\mathrm{N}, \mathrm{P}$ and protein ratio Table (4).

The effect of interaction resulted in high significant increase of $\mathrm{N}$, protein $\%$ and total carbohydrate due to application of $75 \mathrm{mg} / \mathrm{L} \mathrm{BA}$ or $2 \%$ and $3 \%$ yeast extract for the two cultivars (Table 4).

The high level of BA as well as yeast $(75 \mathrm{mg} / \mathrm{L}$ or $3 \mathrm{~g} / \mathrm{L})$ showed the highest significant content of $\mathrm{P}$ and $\mathrm{K}$.

Table (4) shows also the effect of BA or yeast on the anti-nutritional factor (Vicine), cultivar N2 possess the high level of this compound compared to cultivar M3, however the percentage of reduction was the same (Table 4).

Treatment with the highest concentration of yeast $(3 \mathrm{~g} / \mathrm{L})$ resulted in the lowest content of vicine, meanwhile BA at $75 \mathrm{mg} / \mathrm{L}$ shows the highest reduction percentage (Table4)

Interaction between cultivar and treatments indicates that application of $75 \mathrm{mg} / \mathrm{L} \mathrm{BA}$ to $\mathrm{M} 3$ cultivar exhibits the least amount of vicine as well as the highest percentage of reduction of this antinutritional compound (Table 4) 
Table 4: Effect of benzyladenine or yeast extract on some biochemical constituents of yielded seeds of Misr 3 and Nubaria 2 Cultivars (Combined analysis of two seasons)

\begin{tabular}{|c|c|c|c|c|c|c|c|c|}
\hline & & N\% & P \% & K\% & Protein\% & $\begin{array}{c}\text { Total } \\
\text { Carbohydrate }\end{array}$ & Vicine & $\begin{array}{c}\% \\
\text { Reduction }\end{array}$ \\
\hline \multicolumn{9}{|c|}{ Effect of cultivars } \\
\hline & $4.16 \mathrm{a}$ & $0.35 b$ & $1.73 b$ & $23.95 \mathrm{a}$ & $53.76 \mathrm{a}$ & $242.3 b$ & $26.77 \mathrm{a}$ \\
\hline \multicolumn{2}{|l|}{ Nubaria2 } & $4.08 \mathrm{~b}$ & $0.39 \mathrm{a}$ & $2.18 \mathrm{a}$ & $23.45 b$ & $52.32 b$ & $324.0 \mathrm{a}$ & $26.55 \mathrm{a}$ \\
\hline \multicolumn{2}{|c|}{ LSD at $5 \%$} & 0.06 & 0.04 & 0.04 & 0.31 & 0.47 & 4.47 & 2.32 \\
\hline \multicolumn{9}{|c|}{ Effect of Treatment } \\
\hline \multicolumn{2}{|c|}{ Control } & $3.78 \mathrm{f}$ & $0.31 \mathrm{c}$ & $1.51 \mathrm{c}$ & $21.71 \mathrm{f}$ & $50.80 \mathrm{~d}$ & $408.7 \mathrm{a}$ & $0.00 \mathrm{f}$ \\
\hline \multicolumn{2}{|c|}{ BA (25mg/L) } & $3.88 \mathrm{c}$ & $0.35 b$ & $1.83 \mathrm{~d}$ & $22.30 \mathrm{e}$ & $52.51 \mathrm{c}$ & $353.7 b$ & $13.95 \mathrm{e}$ \\
\hline \multicolumn{2}{|c|}{ BA (50mg/L) } & $4.13 c$ & $039 a$ & $2.023 \mathrm{c}$ & $23.75 c$ & $53.98 b$ & $269.4 \mathrm{c}$ & $35.04 \mathrm{bc}$ \\
\hline \multicolumn{2}{|c|}{ BA (75mg/L) } & $4.38 \mathrm{a}$ & $0.41 \mathrm{a}$ & $2.32 \mathrm{a}$ & $25.16 \mathrm{a}$ & $55.04 \mathrm{a}$ & $238.3 \mathrm{e}$ & $42.33 \mathrm{a}$ \\
\hline \multicolumn{2}{|c|}{ Yeast $(1 \mathrm{~g} / \mathrm{L})$} & $4.05 \mathrm{~d}$ & $0.35 b$ & $1.88 \mathrm{~d}$ & $23.27 \mathrm{~d}$ & $51.30 \mathrm{~d}$ & $258.1 d$ & $36.14 b$ \\
\hline \multicolumn{2}{|c|}{ Yeast $(2 \mathrm{~g} / \mathrm{L})$} & $4.36 \mathrm{a}$ & $0.39 \mathrm{a}$ & $2.02 \mathrm{c}$ & $25.09 \mathrm{a}$ & $53.37 \mathrm{~b}$ & $234.1 \mathrm{c}$ & $33.51 \mathrm{c}$ \\
\hline \multicolumn{2}{|c|}{ Yeast $(3 \mathrm{~g} / \mathrm{L})$} & $4.28 b$ & $0.41 \mathrm{a}$ & $2.09 \mathrm{~b}$ & $24.61 b$ & $54.07 \mathrm{~b}$ & $220.0 \mathrm{f}$ & $25.65 d$ \\
\hline \multicolumn{2}{|c|}{ LSD at $5 \%$} & 0.08 & 0.04 & 0.05 & 0.45 & 0.51 & 5.90 & 1.68 \\
\hline \multicolumn{9}{|c|}{ Effect of Interaction } \\
\hline \multirow{7}{*}{$\begin{array}{l}\text { Misr } \\
3\end{array}$} & Control & $3.84 \mathrm{e}$ & $0.29 \mathrm{~g}$ & $1.37 \mathrm{~h}$ & $22.08 \mathrm{e}$ & $52.61 \mathrm{e}$ & $352.31 \mathrm{c}$ & $0.00 \mathrm{j}$ \\
\hline & BA $(25 \mathrm{mg} / \mathrm{L})$ & $4.06 \mathrm{~d}$ & $0.34 \mathrm{defg}$ & $1.68 \mathrm{fg}$ & $23.33 d$ & $53.90 \mathrm{bc}$ & $290.74 \mathrm{e}$ & $17.48 \mathrm{~h}$ \\
\hline & BA $(50 \mathrm{mg} / \mathrm{L})$ & $4.23 b c$ & $0.37 \mathrm{bcdef}$ & $1.88 \mathrm{e}$ & $24.34 \mathrm{bc}$ & $54.52 \mathrm{ab}$ & $20435 \mathrm{i}$ & $42.00 \mathrm{~b}$ \\
\hline & BA $(75 \mathrm{mg} / \mathrm{L})$ & $4.38 \mathrm{a}$ & $0.39 \mathrm{bcde}$ & $1.96 \mathrm{~d}$ & $25.19 \mathrm{a}$ & $55.11 \mathrm{a}$ & $185.32 \mathrm{j}$ & $47.30 \mathrm{a}$ \\
\hline & Yeast $(1 \mathrm{~g} / \mathrm{L})$ & $4.04 \mathrm{~d}$ & $0.33 \mathrm{efg}$ & $1.63 \mathrm{~g}$ & $23.25 \mathrm{~d}$ & $51.49 f$ & $243.02 \mathrm{~g}$ & $31.01 \mathrm{e}$ \\
\hline & Yeast $(2 \mathrm{~g} / \mathrm{L})$ & $4.42 \mathrm{a}$ & $0.36 \mathrm{cdef}$ & $1.75 \mathrm{f}$ & $25.42 \mathrm{a}$ & $53.63 \mathrm{~cd}$ & $220.28 \mathrm{~h}$ & $27.58 f$ \\
\hline & Yeast $(3 \mathrm{~g} / \mathrm{L})$ & $418 \mathrm{c}$ & 0.38 bcdef & $1.85 \mathrm{e}$ & $24.02 \mathrm{c}$ & $55.07 \mathrm{a}$ & $200.39 \mathrm{i}$ & $22.00 \mathrm{~g}$ \\
\hline \multirow{7}{*}{$\begin{array}{c}\text { Nubaria } \\
2\end{array}$} & Control & $3.71 \mathrm{f}$ & $0.32 \mathrm{fg}$ & $1.64 \mathrm{~g}$ & $21.33 f$ & $48.98 \mathrm{~g}$ & $465.12 \mathrm{a}$ & $0.00 \mathrm{j}$ \\
\hline & BA $(25 \mathrm{mg} / \mathrm{L})$ & $3.70 \mathrm{f}$ & $0.35 \mathrm{defg}$ & $1.97 \mathrm{~d}$ & $21.28 \mathrm{f}$ & $51.12 \mathrm{f}$ & $416.68 b$ & $10.41 \mathrm{j}$ \\
\hline & BA $(50 \mathrm{mg} / \mathrm{L})$ & $4.03 \mathrm{~d}$ & 040abcd & $2.17 \mathrm{c}$ & $23.15 d$ & $53.45 \mathrm{~cd}$ & $334.51 d$ & $28.08 \mathrm{f}$ \\
\hline & BA $(75 \mathrm{mg} / \mathrm{L})$ & $4.37 \mathrm{a}$ & $0.43 \mathrm{ab}$ & $2.69 \mathrm{a}$ & $25.12 \mathrm{a}$ & $54.98 \mathrm{f}$ & $291.32 \mathrm{e}$ & $37.37 \mathrm{~d}$ \\
\hline & Yeast (1g/L) & $4.05 \mathrm{~d}$ & $0.36 \mathrm{cdef}$ & $2.12 \mathrm{c}$ & $23.30 \mathrm{~d}$ & $51.10 \mathrm{f}$ & $273.08 \mathrm{f}$ & $41.28 \mathrm{bc}$ \\
\hline & Yeast $(2 \mathrm{~g} / \mathrm{L})$ & $4.31 \mathrm{ab}$ & $0.42 \mathrm{abc}$ & $2.30 \mathrm{~b}$ & $24.76 \mathrm{ab}$ & $53.51 \mathrm{~cd}$ & $247.88 \mathrm{~g}$ & $39.44 \mathrm{~cd}$ \\
\hline & Yeast $(3 \mathrm{~g} / \mathrm{L})$ & $4.38 \mathrm{a}$ & $0.45 \mathrm{a}$ & $2.34 \mathrm{~b}$ & $25.20 \mathrm{a}$ & $53.07 \mathrm{de}$ & $239.67 \mathrm{~g}$ & $29.29 \mathrm{ef}$ \\
\hline \multicolumn{2}{|c|}{ LSD at $5 \%$} & 0.11 & 0.05 & 0.08 & 0.64 & 0.72 & & 2.37 \\
\hline
\end{tabular}

\section{Discussion} Egypt.

The present study focused on faba bean (Vicia bean L.) which is one of the important crop in

The present investigation was taken to assess the increase quality and quantity of two cultivars of this crop (Misr 3 and Nubaria) grown in new reclaimed sandy soil in Egypt.

The results of the present study indicate that the two higher concentration of BA $(50,75 \mathrm{mg} / \mathrm{L})$ or yeast extract (2, $3 \mathrm{~g} / \mathrm{L})$ (Table 1) exhibited the highest effecton growth parameters. Stimulation of BA on growth was previously reported by other researchers Vijay and Laxmi (2001) on beans; Patil et al., (2002) on soybean; Amin et al., (2007) on Maize and Ibrahim and El-Mugadam (2015) on tomato. In Addition, other investigators found that kinetin had an enhancement effect on growth of different plants (Ibrahim et al., 2006 on lentil; El-Saeid et al., 2011 on white lupine and Sadek et al., 2013 on faba bean).

With regard to yeast treatments, the increase of the studied criteria wereconfirmed by the finding of other reports; Abou El-Yazied and Mady (2012), Kamal and Ghoniem (2012) and Mahmoud et al., (2013) on faba bean and Marzauk et al., (2014) on pea plants. Increases of bean vegetative growth by yeast application of the present study might be attributed to the content different nutrients such as minerals, amino acids and vitaminsof yeast (Barnett et al., 1990) that may play a vital role in improving growth.

Photosynthetic pigments (Table 2) clarifying the effective role of BA or yeast on the two varieties. These results emphasize the pervious founding by other researchers. As to BA (Ibrahim and El-Mugadern, (2015) on tomato). Preceding studies by Xie et al., (2004) reported that cytokinins stimulate chlorophyll biosynthesis and chloroplast differentiation of wheat plants.

Concerning treatment with yeast extract on the photosynthetic pigments in the present study was supported by other investigators (Mady, 2009 and Abbas, 2013, on faba bean, Dawood et al., 2013on soybean).Later, El-Serafy (2018) on Hibiscus sabdariffa L. the increase of chlorophylls content may be due to the fact that yeast extract contains cobalt and manganese which both have important role in the 
production of chlorophylls (El-Desuki et al., 2014on tomato and AbedNasser et al., 2019 on Lens eulinaris). Other researcher reported that kinetin is a member of cytokines stimulated endogenous (IAA, GA3 and cytokinins) in different leguminous plants (Ibrahim et al., 2006 on lentil, El-Saied et al., 2011 on lupine and Sadak et al., 2013on faba bean) accompanied by increase of growth as well as number and weight of pods and seeds. The significant increase in yield (Table 3) the present studied by BA application may be assigned to the influence of BA on source sink relation in reproductive development by manipulating photo assimilated production and stimulate translocate to seed development (Solaimalai et al., 2001and Patil et al., 2002). This view is in close with the conclusion of their researches (Jameson and Song (2016) and Cora et al., (2018).

Concerning yeast extract, application of this bio-stimulant of faba bean plants (Mady, 2009; Marzauk et al., 2014; Abo El-Hamad, 2015; Khattab et al., 2015) resulted in increase of the yield.

It is work to mention that yeast extract has a beneficial role during plant reproductive phase due to its control of vital compounds as amino acids, minerals, vitamins and endogenous hormones (auxins and cytokinins) (Barentt et al., 1999). Moreover, free amino acids allow plants save energy for their building. Authors indicate that improvement of photosynthetic pigments in response to foliar application of yeast extract might be attributed to its bio-regulator role which affects the balance between photosynthesis and respiration (Olaiya 2010) and delaying the aging of leaves by reducing the degradation of chlorophyll and enhancing the protein RNA synthesis due to the role of cytokinins in yeast extract (Shalaby and El-Nady, 2008).

Increase of carotenoids level in treated plants in the present study by BA or yeast extract could be a further support to explain the high level of chlorophylls, since carotenoids acts as a protective agent from photo-oxidation (Axelsson 1981). They are important antioxidant, as they scavenge and dissipate singlet oxygen through direct quenching of triplet-state of chlorophyll molecule and dissipate harmless as a heat (Pallet and Young 1993).

Treatment of faba bean plants with the highest concentration of BA $(75 \mathrm{mg} / \mathrm{l})$ or yeast $(3 \%)$ increased the yield pods and seeds/plant (Table 3 ).

Increase of faba bean yielded pods and seeds by application of BA (Table 3) might attributed to the increase of vegetative growth, number of branches and leaves as well as photosynthetic pigments, which in turn lead to increase of photosynthetic assimilates production translocate to the production organs during maturation and ripening stages of pods and seeds. Worth to be mention development and reconstruction especially in critical of plant development (Amin et al., 2011 on onion and El-Awadi et al., 2016 on faba bean and Teixeira et al., 2018 on soybean).

In addition, yeast extract contains many nutrients and vitamins especially vitamin B family. They are grouped due to its similarity in their function as coenzyme and they are well characteristics for their role in metabolic pathway energy production and control metabolism, including carbon assimilation and respiration (Fitzpatrick and Chapman, 2020).

As to the effect of yeast on endogenous hormones (Mady 2009 and Abou El-Yazied and Mady 2011) found increase of auxins and cytokinins content due to application of yeast extract to faba bean and tomato plants accompanied by increase of yield. These results shed light on the role of these hormones in increase translocation from source to sink organs (Amanullah et al., 2010).

Considering the chemical composition of seeds (Table 4) BA or Yeast extract increase carbohydrate, protein, N, P, K contents of the yielded seeds. Similar findings were obtained by other researchers with regard to application of BA (Ibrahim et al., 2007 and Sadek et al., 2013on faba bean). They attributed that to encourage absorption of nitrogen from the soil and activation of the photosynthesis process, hence these processes might increase protein and carbohydrate percentage of the seeds (El-Beheidi et al., 1991). In addition, Amin et al., (2014) reported increase in NPK ratio as well as crude protein percentage yield of lupine plant through foliar spraying with kinetin.

As to effect of yeast on chemical constituents of yielded seed, several researches exhibited increase of protein, and nitrogen as well as carbohydrate and NPK in leguminous plants (Khalil and Ismael (2010) on lupines, Dawood et al., (2013) on soybean, and Marzauk et al., (2014) on faba bean). They reported increase of nitrogen and protein as well NPK, and refereed that to the different vital compounds in yeast.

In spite of many benefits of faba bean seeds as they contain antinutrional factors vicine $(2,6$ diamino-4, 5dihydroxy pyrimidine, 5, B-glucopyranoside). This compound causes fauvism (hemolysis in some human individuals who suffer of deficiency of enzyme G6PS). These constituents may cause 
health problem in particular cases and restriction faba bean usage. The author tried to study the effect of treatment plants with BA or yeast to decrease the percentage of this compound in the yielded seed of faba bean to increase the benefits of this important crop. The highest concentration of BA $(75 \mathrm{mg} / \mathrm{l})$ shows the lowest content of vicine followed by the highest concentration of yeast (3\%) in faba bean seed variety (M3). In addition, the highest reduction of this anti-nutritional compound attained by $(75 \mathrm{mg} / \mathrm{l}) \mathrm{BA}$ with respect to variety (M3) followed by treatment with yeast extract (1\%) to N2 variety. Previous researchers found that application of some growth regulators decreased the content of vicine (Gaber et al., 2000 and Sadak et al., 2013).Another authors recorded decreased of this compound (vicine) by treatments of faba bean by some vitamins and anti-nutrients (El-Bassiouny et al., 2005). The reduction of the content of vicine by BA or yeast extract application allocated to the effect of these factors on metabolic pathway of vicine precursor (orotic acid) formation which responsible for the formation of pyrmidine ring of these toxic constituents (Brown and Roberts 1972).

It is clear that variety (N2) possess high level of vicine compared to variety (M) (Table 4) Bjerg et al., (1985) declared that both environmental and genetic factors affect the content of favism causative agents in faba bean seeds.

\section{Conclusion}

Finally it can concluded that the treatment faba bean plants with benzyleadenine (BA) $75 \mathrm{mg} / \mathrm{L}$ followed by treatment with yeast extract $3 \mathrm{~g} / \mathrm{L}$ surpassed other treatment and showed the maximum increase of seed yield as well as nutritional constituents of seeds.

\section{References}

Abbas, S.M., 2013. The influence of biostimulants on the growth and on the biochemical composition of Vicia faba CV. Giza 3 beans. Romanian Biotechnological Letters, 18 (2):6061-6068.

Abdel-Baky, Y.R., H.F. Abouziena, A.A. Amin, et al., 2019. Improve quality and productivity of some faba bean cultivars with foliar application of fulvic acid. Bull. Nat. Res. Cent., 43, 2, https://doi.org/10.1186/s42269-018-0040-3.

Abed Nasser, B., S.H. Hussein, F. Saddam and H. Abed Noor 2019 Study the effect of dry bread yeast Saccharomyces cerevisiae, in some qualities of vegetative growth and nutritional status of the lensculinaris. Plant Archives, 19:1101-1106.

Abo El-Hamad A.S., M.M. Ibrahim, N.A. Azzaz, Y.A.M. Khalifa and H.A. Ahmed, 2015. Effect of foliar application with salicylic acid and yeast extract on production and quality of two faba bean (Vicia faba L.) varieties. Minia J. Agric. Res. Develop., 35:327-347.

Abou EL-Yazied, A. and M.A. Mady, 2012. Effect of Boron and Yeast Extract Foliar Application on Growth, Pod Setting and both Green Pod and Seed Yield of Broad Bean (Vicia faba L). J. Am. Sci., 8 (4):517-533.

Abou El-Yazied, A. and M.A. Mady, 2011. Effect of Naphthalene Acetic Acid and Yeast Extract on Growth and Productivity of Tomato (Lycopersicon esculentum Mill.) Plants. Research Journal of Agriculture and Biological Sciences, 7 (2): 271-281.

Amanullah, M.M., S. Sekar and S. Vincent, 2010. Plant Growth Substances in Crop Production: A Review. Asian Journal of Plant Sciences, 9 (4): 215-222.

Amin A.A., M.E. El-Awadi, M.G. Dawood, F.A.E. Gharib and E.A. Hassan, 2014. Kinetin and Tryptophan Enhance Yield and Production Efficiency of Lupine (Lupinus termis L.) Plants. World Rural Observation, 6 (4): 50-56.

Amin, A.A., ElSh.M. Rashad, M.S. Hassanein and Nabila, M. Zaki, 2007. Response of Some White Maize Hybrids to Foliar Spray with Benzyl Adenine. Research Journal of Agriculture and Biological Sciences, 3 (6): 648-656.

Amin, A.A., Gharib, Fatma A.E., El-Awadi, M. Rashad, and M. El-Sherbeny, 2011. Physiological response of onion plants to foliar application of putrescine and glutamine. Scientia Horticulturae, 129 (3):353-360.

AOAC (Association of official agriculture chemists), 2000. Official methods of analysis, 17th edn.Association of official agriculture chemists, Gaithersburg. 
Axelsson L.C., B. Klockare and A. Sandelius, 1981. The function of carotenoids during chloroplast III Protection of prolamellar body and enzyme for chlorophyll synthesis from photodestruction sensitized by early forms of chlorophyll. In proc. $5^{\text {th }}$ Int. Cong on Photosynthesis Halkidisk.Greecz, 295-304.

Bakry, B.A., T.A. Elewa, M.F. El karamany, M.S. Zeidan and M.M. Tawfik, 2011. Effect of Row Spacing on Yield and its Components of Some Faba Bean Varieties under Newly Reclaimed Sandy Soil Condition. World Journal of Agricultural Sciences, 7 (1): 68-72.

Barnett J.A. Barnett, R.W. Payne, and D. Yarrow, 1990. Yeast Characteristics and Identification (second ed.), Press, Cambridge Univ., London, UK 1012.

Batheena A.B., H.H. Salewa, S. Furqan and A. Hameeda 2019. Study the effect of dry bread yeast Saccharomyces cerevisiae, in some qualities of vegetative growth and nutritional status of the Lens culinaris. Plant Archives, 19 (2):1101-1106.

Bjerg, B., J.C.N. Knutsen, O. Oleson, M.M. Poulsen and H. Sorensen, 1985. Quantitative analysis and inheritance of vicine and convicine content in seeds of Vicia faba L. Z. Pflanzenzuecht, 94:135135.

Brown E.G. and F.M. Roberts, 1972. Formation of vicine and convicine by Vicia faba. Phytochemistry, 11 (11): 3203-3206.

Chapman, H.D., and P.F. Pratt, 1978. Methods of Analysis for Soils, Plant and Water.Univ. California, Div. Agric. Sci. Publ., 4034:162-165.

Collier, H.B., 1976. The estimation of vicine in faba beans by an ultraviolet spectrophotometric method. Canadian Institute of Food Science and Technology Journal, 9 (3):155-159.

Dawood, M.G., S.R. El-Lethy and M.S. Sadak, 2013. Role of methanol and yeast in improving growth, yield, nutritive value and antioxidants of soybean. World Applied Sci. J., 26: 6-14.

Dawood, M.G., M.S. Sadak, M.M.S. Abdallah, et al., 2019. Influence of biofertilizers on growth and some biochemical aspects of flax cultivars grown under sandy soil conditions. Bull Natl Res Cent 43, 81. https://doi.org/10.1186/s42269-019-0122-x.

Dujardin, P., 2012. The Science of Plants Biostimulants: A Bibliographic Analysis. (Contract 30CE0455515/00-96, Ad hoc study on Biostimulants Products. Brussels: European Commission.

Dubois, M., K.A. Gilles, J.K. Hamilton and P.A. Robers, 1956.Colourimetric method for determination of sugars and related substances.Anal. Chem., 28: 350-356.

El-Awadi, M.E., Sohair K. Ibrahim, Mervat Sh. Sadak, Ebtihal M.Abd Elhamid and Karima M. Gamal El-Din, 2016. Impact of cysteine or proline on growth, some biochemical attributes and yield of faba bean. International Journal of PharmTech. Research, 9:100-106.

El-Bassiouny H.M.S., M.E. Gobarab and A.A. Ramadan, 2005. Effect of antioxidant on growth, yield and favism causative agents in seeds of Vicia faba plants grown reclaimed sandy soil. Egyptian Journal of Agronomy, 4: 281-287.

El-Beheid, M.A., M.H. El sawah and E.A. El-Ghamriny, 1991. Effect of foliar spray with kinetin CCC and GA3 on growth and yield of broad bean plant. Zagazig Journal of Agricultural Research, 18:1935-1945.

El-Desuki, A.A., F.H. Ismaeil, E.J. Wanas, L. Fathy and Abd El-All, 2014. Effect of yeast extract, animo acids and citic acid on onphysioanatomical aspects and productivity of tomato plants grown in late summers season Menoufia J. Agric. Res., 36:859-884.

El-Saeid, H.M., F.A. Hussein, and M.S.A. AbdAlla, 2011. Effect of some bioregulators on white lupine (Lupinus termis) seed yield and its components and on endogenous hormones content in seeds. Electronic Journal of Polish Agricultural Universities, 14 (4):2-2.

El-Serafy, R.S., 2018. Growth and productivity of roselle (Hibiscus sabdariffia L.) as affected by yeast and hummic acid. Scientific Journal of Flowers and Ornamental Plants, 5 (2):195-203.

Fitzpatrick, T.B. and L.M. Chapman, 2020. The importance of thiamine (vitamin B1) in plant health: From crop yield to biofortification. J. Biol. Chem., 295 (34) 12002-12013.

DOI 10.1074/jbc.REV120.010918. 
Gaber, A.M., O.A. El-Shahaby, and A.A. Ramadan, 2002. Effect of some hormonal treatments on chemical composition and Favism causative agents in the yielded seeds of Vicia faba. Egyptian Journal of Physiological Sciences, 24: 17-45.

Gora, M.K., H. Jat, K.C. Jakhar, J. Hemraj and A. Shivran, 2018. Potentiate the productivity of oilseed crops by plant hormonbenzyladenine, (Synthetic cytokinin): A review. Journal of Pharmacognosy and Phytochemistry, 7 (4): 3383-3385.

Ibrahim, S.K., H.M. El-Saeid and Magda Shalaby, 2006. The role of kinetin in flower abscission and yield of lentil plant. Journal of Applied Science Research, 2 (9): 587-591.

Ibrahim, S.K. and Lulwa A. El-Muqadam, 2015. Improving thermotolerance of tomato plants (Lycopersicon esculentummill.) by foliar application of benzyl adenine. Middle East Journal of Applied Sciences, 05 (4): 848-854.

Ibrahim, M.E, M.A. Bekheta, A. El-Moursi and N.A. Gaafar, 2007. Improvement of Growth and Seed Yield Quality of Vicia faba L. Plants as Affected by Application of Some Bioregulators. Australian Journal of Basic and Applied Sciences, 1 (4): 657-666.

Jameson, P.E., and J. Song, 2016. Cytokinin: a key driver of seed yield. Journal of Experimental Botany, 67 (3): 593-606, https://doi.org/10.1093/jxb/erv461.

Kamal, A.M. and K.M. Ghonien, 2012. Impact of some biostimulant on organically cultivated snap bean plant. Egypt J. Appl. Sci., 27:89-104.

Khalil, S.E. and G.I. Ezzat, 2010. Growth, Yield and Seed Quality of Lupinus termis as Affected by Different Soil Moisture Levels and Different Ways of Yeast Application. J. Am. Sci., 6 (8):141153.

Khattab, E.A., C.Y. El-Dewiny, M.H. Afifi, and R.K.M. Khalifa, 2015. Response of some varieties of faba bean to yeast and algae and their impact on yield and its components. Middle East journal of Agriculture, 4:907-913.

Lichtenthaler, H.K., and C. Buschmann, 2001. Chlorophylls and carotenoids: measurement and characterization by UV-VIS spectroscopy. In: Wrolstad RE, Acree TE, An H, Decker EA, Penner MH, Reid DS, Schwartz SJ, Shoemaker CF, Sporns P (eds) Current protocols in food analytical chemistry (CPFA). John Wiley and Sons, New York, F4.3.1-F4.3.8

Mady, M.A., 2009. Effect of foliar application with yeast extract and zinc on fruit setting and yield of faba bean (Vicia faba L). J. Biol. Chem. Environ. Sci., 4 (2): 109-127

Mahmoud, R. Asmaa, EL-Desuki, M., Mona, M. Abdel-Mouty and Aisha, H. Ali, 2013. Effect of Compost Levels and Yeast Extract Application on the Pea Plant Growth, Pod Yield and Quality. Journal of Applied Sciences Research, 9 (1): 149-155.

Marzauk, N.M., M.R. Shafeek, Y.I. Helmy, A.A. Ahmed and Magda, A.F. Shalaby, 2014. Effect of vitamin $\mathrm{E}$ and yeast extract foliar application on growth, pod yield and both green pod and seed yield of broad bean (Vicia faba L.) Middle East J. Appl. Sci., 4 (1): 61-67.

Megawer, E.A., M.A.EL. Ahmed, and S.M. Mohamed, 2011. Performance of five Faba bean varieties under different irrigation intervals and sowing dates in newly reclaimed soil. International Journal of Agronomy and Agricultural Research (Int. J. Agron. Agri. Res.) 10 (4): 57-66.

Olaiya, C.O., 2010. Presowing Bioregulator Seed Treatments Increase the Seedling Growth and Yield of Tomato (Solanum lycopersicon). J. Plant Growth Regul., 29: 349-356. https://doi.org/10.1007/s00344-010-9142-3.

Pallet, KE. and A.J. Young, 1993. Carotenoids In: Alscher RG, Hess JL (eds) Antioxidants in Higher Plants. CRC Press, Boca Raton. Ann. Arbr., London, 60-89.

Patil, R.R., R.D. Deotale, C.N. Hatmode, P.E. Band, V.D. Basole, and T.R. Khobragade, 2002. Influence of 6-benzyladenine on morpho-physiological parameters of soybean. Journal of Soils and Crops, 12 (2): 296-300.

Sadak, M.S., M.G. Dawood, B.A. Bakry and M.F. El-Karamany, 2013. Synergistic effect of indole acetic acid and kinetin on performance, some biochemical constituents and yield of faba bean plant grown under newly reclaimed sandy soil. World J. Agric. Sci., 9: 335-344.

Shalaby, M.E., and F.El. Mohamed, 2008. Application of Saccharomyces cerevisiae as a biocontrol agent against Fusarium infection of sugar beet plants. Acta Biologica Szegediensis, 52 (2):271275.

Solaimalai A., C. Sivakumar, S. Anbumani, T. Suresh, and K. Arulmurugan, 2001. Role of plant growth regulators in rice production.A review. Agricultural Reviews, 2:33-40. 
Teixeira, W.F., E.B. Fagan, L.H. Soares, J.N. Soares, K. Reichardt, and D.D. Neto, 2018. Seed and Foliar Application of Amino Acids Improve Variables of Nitrogen Metabolism and Productivity in Soybean Crop. Front Plant Sci., 9: 396.

Van Oosten, M.J., O. Pepe, S. De Pascale, et al., 2017. The role of biostimulants and bioeffectors as alleviators of abiotic stress in crop plants. Chem. Biol. Technol. Agric. 4,5. https://doi.org/10.1186/s40538-017-0089-5.

Van Staden, J., and N. Crouch, 1996. Benzyladenine and derivatives-their significance and interconversion in plants. Plant Growth Regul., 19: 153-175. https://doi.org/10.1007/BF00024582.

Vijay, L. and V. Laxmi, 2001. Effect of benzyl adenine on dry matter distribution and yield in mug bean. Indian J. Pulses Res., 14: 138-140.

Xie, Z., D. Jiag, T. Dai, Q. Jing, and W. Cao, 2004. Effects of exogenous ABA and cytokinin on leaf photosynthesis and grain protein accumulation in wheat ears cultured in vitro Plant Growth Regul., 44:25-32 